\title{
Explaining Leaving Union Membership by the Degree of Labour Market Attachment Exploring the Case of Germany
}

Leschke, Janine; Vandaele, Kurt

Document Version

Accepted author manuscript

Published in:

Economic and Industrial Democracy

DOI:

10.1177/0143831X15603456

Publication date:

2018

License

Unspecified

Citation for published version (APA):

Leschke, J., \& Vandaele, K. (2018). Explaining Leaving Union Membership by the Degree of Labour Market Attachment: Exploring the Case of Germany. Economic and Industrial Democracy, 39(1), 64-86.

https://doi.org/10.1177/0143831X15603456

Link to publication in CBS Research Portal

\section{General rights}

Copyright and moral rights for the publications made accessible in the public portal are retained by the authors and/or other copyright owners and it is a condition of accessing publications that users recognise and abide by the legal requirements associated with these rights.

\section{Take down policy}

If you believe that this document breaches copyright please contact us (research.lib@cbs.dk) providing details, and we will remove access to the work immediately and investigate your claim. 


\title{
Explaining Leaving Union Membership by the Degree of Labour Market Attachment: Exploring the Case of Germany
}

\author{
Janine Leschke and Kurt Vandaele \\ Journal article (Post print version)
}

\begin{abstract}
This article was originally published in Economic and Industrial Democracy
Published online: September 16, 2015

DOI: $10.1177 / 0143831 X 15603456$
\end{abstract}

Uploaded to Research@CBS: November 2015

Available at:

http://research.cbs.dk/da/publications/explaining-leaving-unionmembership-by-the-degree-of-labour-market-attachment\%2860b46f70-2f8c471b-9927-048db23955c9\%29.html 
Explaining leaving union membership by the degree of labour market attachment: exploring the case of Germany

Janine Leschke, Department of Business and Politics, Copenhagen Business School, Frederiksberg, Tel. 0045 60141878, jle.dbp@cbs.dk

Kurt Vandaele, European Trade Union Institute, Brussels, kvandaele@etui.org

\begin{abstract}
Trade unions in most European countries have not been able to maintain their membership levels in keeping with increasing labour market participation. Little is known to what extent changes in the employment status and other major life-course changes are influencing the unions' member outflow. By particularly stressing the weaker labour market attachment of workers with non-standard contracts, this article contributes to the rather unexplored issue of mainly non-union related reasons for leaving unions. Germany has been selected as a case study because German unions experienced a steady decline in membership, while at the same time non-standard employment arrangements increased considerably and more so than on European average. Using the German Socio-Economic Panel data we construct a labour market attachment variable capturing different degrees of attachment. Our analysis shows the impact of labour market attachment and firm level characteristics on union leaving and points to important differences across gender.
\end{abstract}

Key words: trade union membership, union membership outflow, labour market attachment, non-standard employment, Germany 


\section{Introduction}

Over the last decades trade unions in almost all European countries have difficulties to maintain their membership levels in keeping with increasing labour market participation. As a result, union density is on the decline in most countries, although considerable cross-country differences in density remain (Visser 2013). One factor often put forward by way of explanation for the trend away from unionisation is the flexibilisation of labour markets as evident in the growth of various forms of non-standard employment, including fixed-term employment, involuntary part-time employment, solo self-employment and the like (Schnabel 2012). Workers with non-standard employment contracts are, given their overrepresentation in sectors with traditionally weak or inadequate union presence at the workplace and collective bargaining institutions, less likely than workers with standard contracts to be members of a trade union. At the same time, unions across Europe have been adapting their representation structures and are increasingly taking active steps to recruit these under-represented groups of workers (GumbrellMcCormick 2011; Vandaele and Leschke 2010).

The growth in non-standard employment is good reason for unions to further develop and step up their recruitment efforts, while possibly also devising other revitalisation strategies designed to attract non-standard workers. To be sure, unions are in a much better position to exert an impact, via recruitment strategies, on membership inflow than they are to control membership outflow which is influenced, predominantly, by developments in employment structures and on labour markets. Yet, as an alternative or supplementary union strategy, deployment of a retention-centred strategy could also be a fruitful approach in seeking to diminish a high membership turnover (Oesch 2012). Such a strategy could, especially, be 
important for unions active in economic sectors with a high entry rate of new union members, and these include sectors with predominantly non-standard employment. Insofar as union membership losses are particularly substantial among non-standard workers (Jódar et al. 2011; Oesch 2012), the effort to focus on membership retention could prove equally valuable. However, little is known about the extent to which changes in employment status and major changes occurring in workers' life-cycles (such as child-birth and retirement are influencing membership outflows. Therefore, the central question of this article is to what extent a person's proximity to the labour force as captured by the degree of labour market attachment (LMA) can explain why members leave the union (while controlling for individual and firm-level characteristics). This article thereby contributes to the rather unexplored issue of the mainly nonunion-related reasons why members leave their unions. By doing the analysis separately for men and women, we additionally take account of the fact that the LMA concept has a strong gender dimension (Rubery 2011). It will be argued here, firstly, that union leaving patterns can be explained, in part, by the LMA degree, and, secondly, that outcomes in this respect vary between women and men. Due to data limitations, however, we are not able to make claims on causal relationships between the individual's labour market status and union membership decisions. This article is therefore exploratory with regard to analysing the relationship between mainly non-union related reasons and union leaving.

Germany, the largest economy in Europe and formerly regarded as the quintessential example of a coordinated market economy, has been selected as a case study because both labour market flexibilisation (Kalleberg 2003) and union density decline seem to have been going hand in hand. First of all, unions affiliated to the Deutsche Gewerkschaftsbund (DGB, Confederation of German Trade Unions) - the most important confederation - have been experiencing a steady 
decline in union membership since soon after the German reunification in 1991, resulting in a current density level of 17.7 per cent, i.e. below the EU15 average (OECD.StatExtracts).

Observers have even speculated about the 'parlous' state of German unions (Addison et al. 2006) due to the erosion of the dual system of industrial relations with its on-going shrinkage in the coverage of collective bargaining and works councils (Addison et al. 2010). Although the DGB has recently proved able to more or less consolidate its membership level, this overall stability in union membership is largely attributable to the membership growth within IG Metall, the largest affiliate of DGB, while Ver.di, the second largest DGB affiliate and largest service sector union, continued to experience membership decline until 2012, particularly in the retail sector, albeit at a slower rate than before (Dribbusch 2013). All in all, the consolidation in union membership has not prevented a further decline in union density. Secondly, Germany has experienced a strong increase in non-standard employment arrangements over the last two decades and particularly in response to the so-called Hartz reforms of the early 2000. Such arrangements include regular and marginal part-time employment (so-called 'mini-jobs') as well as forms of self-employment (both 'genuine' and 'bogus') and various forms of temporary employment. In Germany the extent of most of these non-standard forms of employment are above the EU15-average and - as in other EU countries - women are disproportionately affected (Eurostat, online database). As the literature review in the next section will show in more detail, it is precisely these non-standard workers who display a disproportionately high tendency to leave unions.

\section{Leaving the Union: When, Who and Why?}

Previous research on union membership status has contributed to a better understanding of factors surrounding the timing of leaving the union, the characteristics of the leavers and their 
reasons for leaving. First of all, union membership duration seems, generally speaking, to be a positive, albeit declining, function of age, maximising in the mid- to late 40s (Blanchflower 2007; Vaona 2010); this is an observation that might not, however, hold good in relation to the West German case (Schnabel and Wagner 2012). There is evidence also that, with increasing duration of membership, workers become more aware of some of the benefits of being unionised (Gallie 1996:160-164). Other studies on union membership duration suggest that workers' early experiences with unionisation are crucial (Budd 2010). Hence, unions should particularly focus their retention efforts on the early stages of membership, that being the period when the probability of member outflow is at its highest (Vidal et al. 2013; Visser 2002).

Regarding the characteristics of union-leavers, some groups are less likely to resign from membership than others. For instance, studies show that joining the union at a later age is likely to decrease the outflow rate (Oesch 2012; van Rij and Saris 1993). On average, longer job tenure is associated with lower entrance and leaving rates (Oesch 2012). Furthermore, research for the Netherlands demonstrates that the membership outflow is 'lower for men and declined with age, length of the working week, wage levels (up to a ceiling), firm size (nonlinear), the level of unionization at the workplace and the frequency of contacts with the union' (Visser 2002:418). The same study highlights gender differences, insofar as young women with a part-time job and low monthly income and employed in small firms with low unionisation are shown to be more likely than other groups to leave the union. This demonstrates that 'workers who (...) have a smaller probability to join unions tend to coincide with those that have a higher probability to leave them once being members' (Vaona 2010:1093). Contrary to the Dutch findings, however, in the Catalonia branch of the Workers' Commissions (CCOO) most of the above-mentioned personal characteristics are associated with a high membership growth (Jódar et al. 2011). This 
finding might reflect differing recruitment strategies between Dutch and Spanish unions, with the latter being more focused on recruiting immigrant workers (Marino 2012; Martínez Lucio 2013). Having said this, membership outflow is particularly pronounced in sectors such as construction, hotel and catering and retail, all of which are sectors disproportionately characterised by forms of non-standard employment - a fact that applies to both the Catalonian and the broader Spanish context and that testifies to a highly volatile union membership (Jódar et al. 2011; Vidal et al. 2013). Similarly, evidence for Switzerland confirms the higher union exit rates in the private service sectors (Oesch 2012). The importance of local union organisation is confirmed, meanwhile, in the UK context where ex-union members indicate that they would have stayed in the union had they been asked to do so by the union representatives (Waddington 2006). Similarly, union members who joined through contact with a union representative are less likely to leave than those whose membership was via self-registration (Vidal et al. 2013). Finally, industrial action in the workplace is associated with the decision by non-members to join and it is also a factor shown to discourage members from leaving the union (Cregan 2013).

Explanations for membership outflows are probably not simply the reverse of the reasons for joining a union, for they appear to be influenced also by different causes, as has been shown in, for instance, the Australian and Dutch contexts (Buttigieg et al. 2007; Visser 2002:414). Empirical studies on behaviour relating to membership retention and reasons for leaving tend to focus either on union-related reasons for member outflow - as subjectively assessed by the former members in question - or, alternatively, on external events; each approach entails a different underlying premise in terms of union agency. Albeit with variations from one union to another (Waddington 2006), a significant proportion of union members state that their decision to resign was attributable to union-related aspects upon which the unions themselves have some 
direct impact. The aspects in question refer mainly to dissatisfaction or disillusionment with generally local - union representation (Waddington and Kerr, 1999a, 1999b) and to the generally economic - performance of unions (Friedman et al. 2006). In our own empirical analysis, we focus, however, on the significance of external working-life events for explaining union membership outflows. Our choice in this respect is not only determined by the data usedwhich does not allow the exploration of union-related causes - but is motivated also by a strong empirical consensus arising from various case-studies conducted across western Europe that external events can account for at least about half to two thirds of the member outflow (e.g. Buttigieg et al. 2007; Gallie 1996:171-172; Jódar et al. 2011; Oesch 2012; Waddington 2006; Waddington and Kerr 1999b).

In general, external events arising in the context of working life can be divided into two broad categories, namely, those that are demographic in dimension (childbirth, death and outgoing migration) and those that derive from labour market-induced changes in the employment situation (Jódar et al. 2011). The latter category can refer to becoming unemployed (e.g. Bain and Elsheikh 1976), job mobility, making a transition in employment status (e.g. from full- to part-time), or retiring. Gender differences are apparent here, which strengthens the argument to conduct an analysis separately for men and women. There is evidence for the UK that the outflow of men tends to be characterised by union dissatisfaction and being made redundant whereas women are more likely to leave their union due to a changing employment situation (Waddington 2006). Changes in personal or family situation, such as the birth of a child, serious illness or divorce, have also been identified as reasons for leaving the union; and often enough these indeed go hand in hand with changes in employment status. Interestingly, Visser (2002) shows, in relation to the Netherlands, that childbirth is a reason why some women 
leave the union whereas, in the case of men, fatherhood has no significant impact on union membership outflow.

\section{Introducing the Concept of Labour Market Attachment}

The foregoing overview established the importance of analysing the changing labour market position of workers and their attachment to the workplace for explaining union leaving. Here we will thus introduce the LMA concept. Hitherto, to our knowledge, no studies on unionisation have explicitly used the LMA concept, although the concept is not new as such. Indeed, the diversity in the union membership composition has already been explored in, for instance, the Spanish context by using the labour market position of union members (Alós et al. 2009). In this research a typology of four status-consistent groups has been defined, among which the ‘peripherals-in-transition' group, i.e. mostly young male workers with low seniority, has displayed the highest risk of leaving the union at any time, particularly at shorter membership durations (Vidal et al. 2013). Those empirical results in the Spanish context hint at a potential relationship between the degree of LMA and union-leaving patterns.

The LMA concept promises to enable a fuller understanding of union-leaving generated by external events in the working career. LMA can be broadly described as a measure devised to examine the evolving degree of the individual's proximity to the labour force over time; this can be envisaged as a full spectrum ranging from completely economically inactive or detached groups from the labour market, at one extreme, to workers fully attached (e.g. full-time, permanent, dependent) ${ }^{1}$ at the other extreme (Virtanen et al. 2011). In other words, the LMA

\footnotetext{
${ }^{1}$ For an early critical perspective on the so-called "Normalarbeitsverhältnis" and its implications for the union movement, see Mückenberger (1989).
} 
concept assumes 'that there is a gradient in the labour market, with some positions being more strongly attached to the labour market than others' (Waenerlund 2014:8). The LMA concept's usefulness, in our opinion, lies in its dynamic perspective and its possibility to capture both the quantity and the quality of attachment to the labour market, including forms of non-standard employment, irrespective of more subjective perceptions, such as job security, that workers associate with their job.

To our knowledge the approach to LMA is solely inductive. Yet, even though direct reference to the LMA concept is generally lacking, the literature on national labour market institutions, policies and welfare state regimes and their interaction with the psychological, social-cultural and socio-economic factors explaining the labour market participation of certain groups can be used for theoretically framing the different degrees of LMA or the transition between them (Bell 2012). In particular, theories about labour market segmentation (Döringer and Piore 1971) or - in its newer variant - labour market dualisation (e.g. Emmenegger et al. 2012) and how these are historically shaped and continuously reshaped by management practices, capital strategies and processes of ‘creative destruction’ (Reich et al. 1972), influencing the character and organisation of work as well as impacting labour market reforms, are useful for underpinning the theoretical understanding of LMA.

In the context of explaining union leaving, it is possible to establish a link between the LMA concept and unionisation via underpinning it with the social custom theory on unionisation. For understanding why workers join and remain in the union the social custom theory emphasizes the importance of social beliefs, expectations, influence and pressure from union-friendly social networks (family or colleagues at the workplace), the union representation at the workplace and employers' attitudes towards unionisation (Visser 2002). Assumptions 
about a critical mass and a reputation effect are crucial for understanding how a social custom of union membership could be established and sustained. In itself the reputation effect depends on 'the intensity and quality of interaction among workers, and on their beliefs or opinions about the union and union membership' (Visser 2002:408). A minimum level of unionisation is needed before the reputation effect for adhering to the norm of union membership can work (Booth and Chatterji 1993). As union density tends to be generally lower among workers with low or medium LMA (Fitzenberger et al. 2011; Ebbinghaus et al. 2011) where, in all probability, opportunities for contacts with unionised co-workers at the workplace are less available, we assume that the reputation losses stemming from resignation from union membership will be weaker for those workers. For this reason, we expect a higher probability of resignation from union membership among workers with low or medium LMA, with pronounced gender differences as the LMA degree differs between men and women as will be shown in the next section. Also, the social custom theory predicts that the norm of union membership will be difficult to maintain for workers with a high job turnover as it increases possibilities for disobedience with the norm. Furthermore, union membership tenure, reflecting adherence to the norm of membership, will decrease the probability of resigning from union membership. Also, time and again research on the micro-determinants of union membership in Germany points to the importance of union-dominated works councils for explaining unionisation (e.g. Goerke and Pannenberg 2007). We therefore assume that, owing to reputation effects and provision of union services, the local union representation will weaken the probability of union leaving.

Finally, empirical studies using the LMA concept face two methodological challenges: how to measure the strength of the current LMA and how to analyse the changes in LMA? The degree of LMA is usually measured based on cross-sectional or, deemed more suitable, on 
longitudinal administrative or survey data (Virtanen et al. 2011:56). Earlier studies focused on different categorical LMA classes at a given point in time including non-employment, unemployment, temporary and permanent employment (Laux 1997). More recent research has rendered the LMA concept more dynamic and replaced the distinctive LMA classes by different LMA trajectories analysing longitudinal data with more advanced statistical methods. Nonstandard employment figures more prominently in these recent studies, which can be explained by the increasing importance of this category of employment in the labour force and its concurrent better data coverage (Muffels and Fourage, 2002; Virtanen et al., 2011; Waenerlund et al. 2014). Taking into account the previous empirically based LMA literature and its predominant inductive approach, the focus on Germany is particularly interesting given its strong growth in non-standard employment over recent decades.

\section{Putting the LMA concept in the German Labour Market Context}

In this section we aim to identify conceptually different LMA classes within the German labour market. By making reference to earlier research on LMA classes outside Germany and by providing details on non-standard employment, particularly also survey-based evidence, and its institutional embedding in Germany we try to avoid establishing arbitrary LMA classes. Non-standard employment arrangements in Germany have grown steadily over the last two decades (cf. Holst and Dörre 2013) not least due to a growth in services sector employment by more than 10 percentage points over the same period (BA Juli 2012: 32). ${ }^{2}$ The share of regular part-time employment in total employment subject to social security increased markedly from

\footnotetext{
${ }^{2}$ The focus here is on part-time and marginal employment but the same upward trends are observed for selfemployment and temporary employment (European Labour Force Survey, online data bank).
} 
$12 \%$ in 1992 to $25.6 \%$ in 2013 in line with rising female labour market participation (Bundesagentur für Arbeit, Juli 2014). This is also confirmed by Simonson et al (2011) who show by way of using sequence analysis on SOEP data that women's careers have become more discontinuous. Part-time work is often more volatile and transitions to unemployment and inactivity are more frequent than among full-time workers; moreover, the stepping-stone function to full-time jobs is rather limited with Germany having one of the lowest year-to-year upward transitions from part-time to full-time employment (Eurostat, online database). What is more, part-time employment often goes hand in hand with disadvantages in access to social security benefits (Leschke 2013; Schulze Buschoff and Protsch 2008) and low-wage employment is much more pronounced among part-time than among full-time workers (Bosch and Weinkopf 2009:355; Rhein 2013:4). In spite of direct discrimination between part-time and full-time employment being prohibited under the part-time and fixed-term law adopted in 2000 (TzBfG 21.12.2000), for the reasons outlined above, in comparison with full-time employment being strong LMA, we regard regular part-time employment as being medium LMA (see e.g. Fagan and O'Reilly 2003; Simonson et al 2011).

So-called 'mini-jobs' - which are not subject to social security contributions - underwent a particular boost with the Hartz reforms of the early 2000s. As part of the reforms the maximum monthly earnings threshold was raised (currently it stands at 450 euros), the maximum weekly hours rule (previously 15 hours) abolished and the possibility of having a mini-job on top of regular employment was reintroduced. The volume of mini-jobs, both exercised exclusively and on top of regular employment, increased strongly after the Hartz reforms (Bundesagentur für Arbeit 2013). The share of mini-jobs, expressed as a percentage of total employment subject to social security, peaked in December 2004 at 20\%, in March 2015 the share was 18\% (Minijob 
Zentrale 2015). Mini-jobs give access to neither healthcare nor unemployment insurance, and pension benefits accumulated on the basis of mini-jobs are marginal. ${ }^{3}$ Even though the part-time and fixed-term law also applies to mini-jobbers, meaning that no direct discrimination in terms of labour and collective rights is allowed, there is ample evidence that in practice employers frequently do not observe this requirement (for the retail sector see Hinz 2012; for the cleaning sector see Riedel 2012). Looking at both mini-jobs and regular part-time employment combined, more than half of all German women $(52.1 \%)$ and $17.6 \%$ of German men work part-time; $50 \%$ of women part-timers would prefer to work more hours: on average four additional hours for regular part-time workers and nine additional hours for mini-jobbers (Wanger 2011). Considering these features, and particularly the marginal earnings deriving from these jobs, we classify mini-jobs as weak LMA.

Before its encompassing reform in 2007, the German parental leave regulation (flat-rate benefit paid over an extended period) supported lengthy periods outside the labour market for the parent with lower earnings - usually the mother. Since 2007 parental leave has been paid for a shorter period - 14 months - and the benefits are based on former earnings with a comparatively high ceiling; two months are earmarked for the partner. ${ }^{4}$ Not at least because individuals on parental leave have the right to return to their previous employment during a specified period

\footnotetext{
${ }^{3}$ In practice mini-jobbers often have derived health insurance rights via a working spouse or the welfare state.

${ }^{4}$ The take-up of parental leave by fathers has increased markedly since the reform though their parental leave period remains considerably shorter than that of mothers.
} 
(BEEG: 5.12.2006) we classify parental leave as a form of medium LMA (cf. Virtanen et al. 2011). ${ }^{5}$

In spite of the fact that most unemployed persons do take up employment again after a certain period, the likelihood of returning to employment decreases with the length of unemployment. We therefore classify prolonged unemployment of more than 12 months, the official long-term unemployment rate, too as weak LMA. Finally, notwithstanding the fact that some retired persons work in mini-jobs, we consider pensioners to be permanently detached from the labour market. Thus, we distinguish six different LMA classes in the German labour market context: strong LMA (full-time employment), medium LMA (regular part-time employment and parental leave), weak LMA (mini-jobs and unemployment) and detachment (retirement).

\section{Data and Variables}

For analysing the LMA impact on workers' decisions to leave or remain in their union, the German Socio-Economic Panel (SOEP) data is used which provides up-to-date representative longitudinal survey data on individuals and households. ${ }^{6}$ In $2013,30,000$ individual interviews were conducted in around 15,000 households. The individual-level SOEP data contains extensive information on labour market and occupational mobility, income and social security, housing and socio-economic values as well as social orientation. The SOEP uses international standard classifications for concepts such as unemployment, employment, education and the like. We pool

\footnotetext{
${ }^{5} \mathrm{We}$ include persons in this category which have parental leave durations that are longer than the average duration as specified in Statistisches Bundesamt (2015). Given the large gender differences in average duration, we do this separately for men and women.

${ }^{6}$ For information on the SOEP, including questionnaires and codebooks, refer to http://www.diw.de/en/diw_02.c.222725.en/soepinfo.html
} 
the 2007-11 data with the data from the period 2003-7 in order to increase the case numbers in the regression models. We focus on this recent period as labour market flexibilisation has become particularly evident over the last two decades and particularly subsequent to the Hartzreforms.

\section{Dependent variable}

Whereas most SOEP variables are collected on an annual - and some on a monthly - basis, union membership information is, unfortunately, collected only roughly every four years - the latest information is available for 2011. Accordingly, the exact year when a union member left the union is unknown; only the period during which the member resigned from membership can be identified. Our analysis thus remains explorative and does not claim to detect any causal relationships. Yet, in spite of the shortcoming with regard to the periodicity of union membership, to our knowledge in the German context, the SOEP is the only survey that allows combining union leaving and LMA in a dynamic individual level perspective. Thus, focussing on the individual worker between 16 and 64 years within a household as the unit of analysis, for the most recent period, the dependent variable, i.e. ex-union member, is defined as having reported to be a union member in 2007 but no longer in 2011 (see annex 1).

\section{LMA classes as main independent variable}

Regarding our main interest in terms of independent variable, i.e. the LMA classes, the SOEP data provides comprehensive monthly data on labour market status including information on full- 
time, regular and marginal part-time employment, unemployment, parental leave and retirement. ${ }^{7}$ This monthly labour market position calendar information is used for constructing the different LMA classes. ${ }^{8}$ The dynamics of the different labour market statuses are disregarded, i.e. at precisely which point during the four-year period the labour market status changed is not taken into account. Thus, a distinction is made, deductively, between strong, medium and weak LMA as well as detachment - see Table 2 .

Table 1. Constructing the LMA classes

\begin{tabular}{|c|c|c|}
\hline $\begin{array}{l}\text { Labour market } \\
\text { position }\end{array}$ & Indicator & Criteria and priority \\
\hline Strong LMA & Full-time employed & $\geq 42$ months \\
\hline \multicolumn{3}{|l|}{ Medium LMA } \\
\hline $\begin{array}{l}\text { Part-time and full- } \\
\text { time employed }\end{array}$ & $\begin{array}{l}\text { Part-time and full-time } \\
\text { employed }\end{array}$ & $\begin{array}{l}\geq 24 \text { months part-time employed } \& \geq 42 \text { months total regular } \\
\text { employment (either full- or part-time) }\end{array}$ \\
\hline Parental leave & $\begin{array}{l}\text { Longer than average } \\
\text { parental leave }\end{array}$ & $>=4$ months for men and $>=13$ months for women $* *$ \\
\hline \multicolumn{3}{|l|}{ Weak LMA } \\
\hline $\begin{array}{l}\text { Marginal } \\
\text { employment }\end{array}$ & Mini-jobs & $\geq 7$ months $\& \leq 24$ months regular employment \\
\hline Unemployed & Long-term unemployment & $\geq 12$ months* \\
\hline Detachment & Retirement & Retired in the specified period \\
\hline
\end{tabular}

Source: own definitions based on information from the SOEP data

\footnotetext{
${ }^{7}$ Information on temporary as compared to permanent employment is available on a yearly basis only; we include this as additional control in our models.

${ }^{8}$ If applicable, overlapping statuses (e.g. parental leave and part-time employment) are recorded in the data.
} 
Note: four-year period based on retrospective monthly activity calendar; *Overruns marginal employment;

**Overruns marginal employment and unemployment

Strong LMA comprises all persons who worked full-time for at least 42 months out of 48 months. Medium LMA captures those who worked part-time for the majority of the period and at the same time were in regular employment (part-time or full-time) for the large majority of the period. ${ }^{9}$ Thus, for strong LMA and medium LMA (part-time) we follow other studies using the LMA concept (e.g. Muffels and Fouarge, 2002; Furåker and Berglund 2009), focussing on the most frequently observed status in a given period for empirically defining the particular LMA class. Persons with more than average duration of parental leave (more than four months for men and more than 13 months for women) are also attributed to the medium LMA class (parental leave). Marginal employment and unemployment are classified as weak LMA. Persons who had a mini-job for more than seven months and were not regularly employed for more than half of the reference period are classified as weak LMA (marginal employed). ${ }^{10}$ Persons with more than 12 months of unemployment in the reference period are classified as weak LMA (long-term unemployment). Furthermore, since some of the LMA classes are not exclusive, prioritisation had to be applied: parental leave overruns marginal and unemployment, and unemployment

\footnotetext{
${ }^{9}$ We tested two alternative more lax specifications on medium LMA. In the first case the only condition was to have been in part-time employment for the majority of the period ( $\geq 24$ months), in the second case we kept the condition of having been in regular employment (part-time or full-time) for more than 42 months but reduced the threshold for regular part-time to $\geq 12$ month. Naturally, both alternatives increased the case numbers on medium LMA to some degree but rendered very similar multivariate results. We prefer the specification above as it is more distinctive from both strong and weak LMA.

${ }^{10}$ This definition prevents inclusion in this category of persons that are regularly employed and carry out a mini-job as a secondary job.
} 
overruns marginal employment. Finally, all persons retiring in the reference period are classified as detached. ${ }^{11}$

\section{Control variables}

Since the current union status and LMA class are not independent of previous labour market experience over the life-course (Anxo et al. 2007) and current firm level characteristics, a range of control variables are included in the multivariate model (see annex 1 for detailed variable specifications). The SOEP data provides retrospective information to capture the long-term LMA or LMA history with regard to unemployment, part $^{-12}$ and full-time employment experience over the entire employment history of an individual. We also constructed an additional, similar variable for capturing parental leave experience. We include an approximate measure of union membership duration calculated from the retrospective individual-level information on union membership that is available in the SOEP roughly every four years. Further control variables that have been shown to be of relevance in previous research as well as with regard to the microdeterminants of German union membership are introduced (e.g. Fitzenberger et al. 2011): individual-level controls refer to age and education level, while job and workplace characteristics

\footnotetext{
${ }^{11}$ Due to the use of different exclusive LMA classes roughly $12 \%$ of observations are lost. To give an example, due to our strict definition on part-time employment we lose persons who were part-time employed for less than 23 months but more than 6 months unless they were either in parental leave, unemployment or mini-jobs for a sufficiently long period or retiring in the reference period.

${ }^{12}$ Mini-jobs have been included in the calendar of event only from 2005 onwards and can therefore not be captured in a retrospective long-term perspective.
} 
comprise form of contract, recent job (and sectoral) changes ${ }^{13}$, job tenure, firm size, economic sector $^{14}$, net earnings and presence of works councils in the company. For testing the hypotheses, logistic regression models are used to analyse the impact of individual and firm level characteristics and in particular LMA on union-leaving. All results are weighted with the crosssectional weights provided in the SOEP in order to adjust for different sampling probabilities and non-response, and thus ensure that the survey is representative of the corresponding population (Solon et al 2013). Descriptive results for the main variables of interest are shown in annex $2 \mathrm{a}$ (selected individual and firm-level characteristics) and annex 2b (LMA classes).

\section{Multivariate Analysis on Leaving Unions with a Focus on LMA Classes}

In this section findings from our logistic regression models are reported. We are particularly interested in the impact of the LMA classes on resigning from union membership. As previous research has shown that outcomes with regard to labour market transitions, union-leaving and LMA vary substantially by gender, the logistic regressions are run separately for men and women (see also Schnabel and Wagner 2012). We present three different models, separately for men and women; odds ratios are reported throughout.

Table 2. Logistic regression on leaving the union

\footnotetext{
${ }^{13}$ We differentiate between job turnover in the same economic sector and towards another economic sector. In the latter case, we assume that it is more likely that the sector is organised by another union implicating that the unionised worker, at least in theory, needs to resign from the old union and to join the union organising the new sector, hence, interrupting the norm of union membership.

${ }^{14}$ Due to low case numbers for some of the categories we do not include the NACE sector variable with 17 different sectors but use, instead, a variable that distinguishes between private industry, private services and public sector.
} 


\begin{tabular}{|c|c|c|c|c|c|c|}
\hline & $\begin{array}{c}\text { Indiv. } \\
\text { level } \\
\text { (M1) } \\
\text { female }\end{array}$ & $\begin{array}{c}\text { Indiv. and } \\
\text { firm level } \\
\text { (M2) } \\
\text { female }\end{array}$ & $\begin{array}{c}\text { Indiv., firm } \\
\text { level and } \\
\text { LMA (M3) } \\
\text { female }\end{array}$ & $\begin{array}{c}\text { Indiv. } \\
\text { level } \\
\text { (M1) } \\
\text { male }\end{array}$ & $\begin{array}{l}\text { Indiv. } \\
\text { and firm } \\
\text { level } \\
\text { (M2) } \\
\text { male }\end{array}$ & $\begin{array}{c}\text { Indiv., firm } \\
\text { level and } \\
\text { LMA (M3) } \\
\text { male }\end{array}$ \\
\hline \multicolumn{7}{|l|}{ INDIVIDUAL LEVEL } \\
\hline \multicolumn{7}{|l|}{ Ref: vocational education } \\
\hline \multirow[t]{2}{*}{ elementary or lower } & $3.709 * *$ & $3.704^{*}$ & $5.808^{* *}$ & 0.744 & 0.589 & 0.518 \\
\hline & (1.637) & $(2.458)$ & $(3.812)$ & $(0.256)$ & $(0.221)$ & $(0.206)$ \\
\hline \multirow[t]{2}{*}{ higher vocational education } & 1.886 & 1.600 & 1.445 & 0.652 & 0.842 & 0.750 \\
\hline & $(0.970)$ & $(0.929)$ & $(1.058)$ & $(0.287)$ & $(0.376)$ & $(0.337)$ \\
\hline \multirow[t]{2}{*}{ tertiary education } & 1.298 & 1.016 & 1.035 & 0.986 & 0.816 & 0.620 \\
\hline & $(0.443)$ & $(0.476)$ & $(0.542)$ & $(0.431)$ & $(0.430)$ & $(0.394)$ \\
\hline \multicolumn{7}{|c|}{ Ref: TU membership duration $>9 / 10$ yearst } \\
\hline \multirow[t]{2}{*}{ TU duration: 6-9/5-10 years } & 0.583 & 0.963 & 1.316 & 1.128 & 1.906 & 1.850 \\
\hline & $(0.317)$ & $(0.738)$ & $(1.090)$ & $(0.520)$ & $(0.935)$ & $(0.902)$ \\
\hline \multirow[t]{2}{*}{ TU duration: $\leq 5 / 4$ years } & $1.961 *$ & $2.257 *$ & $2.059^{+}$ & $3.877 * * *$ & $3.588 * * *$ & $4.436 * * *$ \\
\hline & $(0.610)$ & $(0.820)$ & $(0.804)$ & $(1.061)$ & $(1.123)$ & $(1.521)$ \\
\hline \multicolumn{7}{|c|}{ FIRM AND WORKPLACE CHARACTERISTICS } \\
\hline \multicolumn{7}{|l|}{ Ref: permanent contract } \\
\hline \multirow[t]{2}{*}{ fixed-term contract } & & 1.551 & 1.012 & & 1.702 & $3.140^{+}$ \\
\hline & & $(0.964)$ & $(0.921)$ & & $(1.329)$ & $(2.040)$ \\
\hline \multirow[t]{2}{*}{ no work contract } & & 1.142 & 0.722 & & 1.653 & 1.820 \\
\hline & & $(0.690)$ & $(0.491)$ & & $(0.872)$ & $(1.091)$ \\
\hline \multicolumn{7}{|l|}{ Ref: firm size: $200-2000$} \\
\hline \multirow[t]{2}{*}{ firm size: $<20$} & & $8.613 * * *$ & $16.359 * * *$ & & 0.811 & 0.439 \\
\hline & & $(5.312)$ & $(11.733)$ & & $(0.499)$ & $(0.293)$ \\
\hline \multirow[t]{2}{*}{ firm size: $20-200$} & & $3.882 * *$ & $6.941 * * *$ & & 0.827 & 0.743 \\
\hline & & $(1.867)$ & $(3.864)$ & & $(0.311)$ & $(0.302)$ \\
\hline \multirow[t]{2}{*}{ firm size: $>2000$} & & 1.996 & $3.710^{*}$ & & 0.714 & 0.679 \\
\hline & & $(0.960)$ & $(2.050)$ & & $(0.257)$ & $(0.238)$ \\
\hline \multirow[t]{2}{*}{ no works council in firm } & & 1.318 & 1.452 & & $3.922 * *$ & $5.294 * * *$ \\
\hline & & $(0.678)$ & $(0.760)$ & & $(1.792)$ & $(2.566)$ \\
\hline \multicolumn{7}{|l|}{ LABOUR MARKET ATTACHMENT } \\
\hline \multicolumn{7}{|l|}{ Ref: strong LMA } \\
\hline \multirow[t]{2}{*}{ medium LMA (part-time) } & & & 0.598 & & & 2.429 \\
\hline & & & $(0.376)$ & & & $(2.769)$ \\
\hline \multirow[t]{2}{*}{ medium LMA (parental leave) } & & & 1.544 & & & 4.508 \\
\hline & & & $(1.905)$ & & & $(4.236)$ \\
\hline weak LMA (mini-jobs) & & & $0.021^{*}$ & & & omitted \\
\hline & & & $(0.037)$ & & & \\
\hline weak LMA (unemployed) & & & 1.582 & & & 1.873 \\
\hline & & & $(1.407)$ & & & $(1.282)$ \\
\hline detachment (retired) & & & $4.088^{*}$ & & & $9.353 * * *$ \\
\hline & & & $(2.869)$ & & & $(5.057)$ \\
\hline long-term strong LMA (full-time) & & & 1.095 & & & 1.006 \\
\hline & & & $(0.064)$ & & & $(0.058)$ \\
\hline long-term medium LMA (part-time) & & & $1.205^{* *}$ & & & 0.844 \\
\hline & & & $(0.081)$ & & & $(0.126)$ \\
\hline long-term medium LMA (parental 1.) & & & 1.036 & & & 1.081 \\
\hline & & & $(0.023)$ & & & $(0.090)$ \\
\hline long-term weak LMA (unempl.) & & & 1.099 & & & 1.118 \\
\hline & & & $(0.306)$ & & & $(0.153)$ \\
\hline
\end{tabular}




\begin{tabular}{|l|l|l|l|l|l|l|}
\hline Constant & $0.108^{* *}$ & $0.007^{* * *}$ & 0.042 & $0.159^{* *}$ & 0.406 & 0.864 \\
\hline & $(0.094)$ & $(0.009)$ & $(0.082)$ & $(0.116)$ & $(0.410)$ & $(1.477)$ \\
\hline & & & & & & \\
\hline Pseudo R2 & & & & & & \\
\hline Prob > chi2 & 0.0571 & 0.1858 & 0.2621 & 0.0705 & 0.1583 & 0.2318 \\
\hline Count R2 & 0.0096 & 0.0000 & 0.0000 & 0.0000 & 0.0001 & 0.0000 \\
\hline Observations & 0.695 & 0.730 & 0.773 & 0.792 & 0.822 & 0.809 \\
\hline
\end{tabular}

Note: odds ratios reported, robust standard errors in brackets, standard errors allow for intra-group correlation using person ID as the cluster variable. Pooled and weighted data.

Additional controls (not significant): age, economic sector, recent job (and sectoral) change, job tenure, net earnings and survey year.

${ }^{+} \mathrm{p}<0.1{ }^{*} \mathrm{p}<0.05 ;{ }^{* *} \mathrm{p}<0.01 ;{ }^{* * *} \mathrm{p}<0.001$

$\dagger$ The uneven categories are due to the fact that we pooled two different waves of the data and that the union information was recorded in slightly varying intervals.

Source: SOEP, version 28.

Table 2 illustrate that union leaving seems to be time-dependent, with relatively new union members being significantly more likely to leave the union during the reference period than those with long union membership. This is true across gender and stable for all three specifications, though only at the 10 percent level in the full model for women. Also women with elementary or lower education have higher odds for union leaving taking those with vocational education as the reference. For testing whether works councils will weaken the probability of union leaving, owing to reputation effects and the provision of union services, model 2 introduces the firm and sectoral characteristics as surveyed in the beginning of the reference period (2003 and 2007, respectively) on top of the individual level characteristics (model 1). Whereas the absence of works councils is highly significant for explaining why male union members leave the union, for female union members the firm size seems to matter. Taking large firms with 200-2000 workers as the reference, women employed in very small and small and 
medium-sized firms are more likely to leave the union. In contrast to the descriptive results (annex 2a) which show a clear increasing tendency in leaving unions with job and particularly sectoral change, once we include this variable in the regression model and control for other firmlevel and individual characteristics (M2) as well as LMA (M3) we do not find a significant effect for either men or women.

In a last step, we add the LMA class variables as well as four continuous variables capturing the strengths of LMA prior to the reference period. ${ }^{15}$ Most of the previous estimates on the individual, firm and sectoral characteristics are robust. Exceptions are being employed in very large firms which becomes, in this model, significant for women, although the impact of this characteristic on resigning from union membership is smaller than the effect of being employed in very small and small and medium-sized firms. Moreover, according to the full model, male fixed-term workers have higher odds to leave the union than permanent workers though this effect is significant at the 10 percent level only. Regarding the LMA classes the descriptive results in annex $2 b$ hint to a relationship between the degree of current LMA and union leaving with workers with strong LMA having the lowest leaving rates, those with medium and weak LMA intermediate ones for the most part and those retiring in the reference period the highest ones. However, when including the LMA classes in the model together with individual and firm level characteristics few effects turn out to be significant. For women the odds of union leaving increase with the extent to which they have worked part-time over the life course (long-term medium LMA) rather than with regard to their current medium LMA. Furthermore, a rather counter-intuitive finding is that unionised women with weak LMA due to mini-jobs are significantly less likely to leave the union than members with strong LMA.

\footnotetext{
${ }^{15}$ LMA classes on mini-jobs for men are dropped in the model due to too low case numbers.
} 
However, this finding is based on small case numbers and, what is more, the confidence interval is relatively large (not shown). Also, model 3 shows no positive association between weak LMA due to long-term unemployment and union leaving, although the effect is positive and significant when running a model on individual-level characteristics and the LMA variable alone (not shown). As soon as we additionally include firm and sectoral characteristics (measured in 2007 and thus before the respective unemployment period), this effect becomes insignificant. Also medium LMA due to parental leave has no effect on union leaving according to our model. ${ }^{16}$ Finally, as has been shown in previous research, the probability of union leaving is significantly higher for both male and female members detached from the labour market due to having retired during the reference period.

\section{Discussion}

In this article, we explored the possible influence of LMA for explaining union leaving in Germany by controlling for individual and firm-level characteristics. Given that the crucial union membership variable is only measured roughly every four years, no causality statements could be made between leaving union membership and the role of the individual's attachment to the labour market. Still, by making reference to the relevant literature on union leaving and on the industrial relations system in Germany, we can interpret the findings of the multivariate analysis.

With regard to the individual characteristics the empirical results clearly confirm previous research on a negative relationship between union membership duration and union leaving. This finding, being significant for both sexes, although more outspoken for men, might

\footnotetext{
${ }^{16}$ A positive impact on member outflow could be expected for persons with prolonged parental leave periods but this cannot be tested here due to low case numbers.
} 
partly reflect early dissatisfaction with the union performance. It suggests that unions should particularly pay attention to the early stages of union membership, as adherence to the norm of union membership is relatively weak at this time, making the probability of resignation considerably higher. Age in itself appears to have no influence on union leaving, although we do not know at what age exactly an individual has joined the union which might be of importance for explaining union leaving.

Analysing the remaining possible drivers for union leaving, remarkable differences between men and women appear. The level of education seems only to matter for women: women with elementary or lower education are significantly associated with union leaving using those with vocational education as a reference. Turning to the firm characteristics, no significant effects can be found between job and sectoral mobility or the broad economic sector and union leaving in the multivariate model. We find significant effects though in terms of contract type, works councils' and firm size influence on union leaving though with important gender differences. For men having a fixed-term contract as compared to a permanent one is associated with higher odds of leaving the union though only at the 10 percent significant level and only in the full model. Fixed-term employment can be perceived as another dimension of reduced labour market attachment. Works councils are not important only as 'recruitment machines' (Behrens 2009): our results indicate also that they are 'retention devices', although the latter seems to hold true only for men and not for women. Probably because women - including unionised women tend to be employed in economic sectors less covered by works councils, the retention effect of works councils on union membership among women is insignificant. Additionally, in contrast to men, women are resigning from union membership in very small firms particularly, but also in 
small and medium-sized ones and, to a lesser degree, in very large companies with a workforce of more than 2,000 employees (as has been found in the Dutch case, see Visser 2002).

Therefore, it looks as if there is more to explaining the differences between men and women in union leaving than referring to the simple fact that women are disproportionately employed in companies and economic sectors characterised by a lack of workers' representation and voice. Indeed, surveys on the German works councils found that women have become more represented on these bodies, albeit with notable sectoral division, but that the works councils are far less frequently chaired by women than by men and their responsiveness to gender issues is rather underdeveloped, particularly in small and medium-sized companies (Klenner and Lindecke 2003; Klenner et al. 2013). This finding echoes previous research for the UK that has hinted at the fact that either women receive the same help and contact as men but require more or different support from their union or, alternatively, they receive less support than men due to being more frequently employed in small workplaces or because of the 'gendered nature of local union activities and the tendency to exclude women from many local activities' (Waddington and Kerr 1999b:194).

With regard to the LMA classes, for both men and women the multivariate model shows - not surprisingly - that the strongest predictor for leaving the union is detachment from the labour market. It is worthwhile noting here that $20 \%$ of the union membership in the DGB affiliated unions consists of pensioners (Dribbusch and Birke 2014:4). It might appear at a first glance that unions should probably not worry too much about losing members who retire as their future lies in attracting and retaining young members rather than having pensioners among their membership. As Waddington and Kerr (1999b:190) indicate, it is 'unlikely that retired members will have marked impact on the recruitment of young workers' given that like-by-like 
recruitment is considered effective for attracting new members to the union. However, it also means that unions need to step up their efforts to recruit young(er) workers in order to maintain and increase their membership while offsetting the substantial number of members who leave the union due to detachment (Holst et al. 2014).

Our model reveals also that the presence of members with medium LMA (part-time) and thus a weaker union membership norm - seems to explain union leaving behaviour though only for women and only with regard to long-term medium LMA (part-time), measured retrospectively. ${ }^{17}$ An explanation could be that for many women in Germany medium LMA is the norm due to, among other things, a lack of adequate work-life balance policies at both the institutional (e.g. child-care) and firm level (e.g. flexible working hours), alongside the influence of prevailing traditional norms and values. Thus, the current unions' retention strategies, whether based on the organising or the servicing model (on the latter, see Thomas 2013), or both, might prove strategies that are less adequate for minimising the outflow of members who are employed in economic sectors with a high incidence of medium LMA due to part-time work. On the other hand, medium LMA due to parental leave is not associated with union leaving, which likely is due to the right to return to their previous employment; moreover a reduced membership fee applies.

Finally, while unemployed members account only for 7\% of the DGB unions' total membership (Dribbusch and Birke 2014:4), which is a lower percentage than the share of pensioners, we can only find a positive relationship between weak LMA due to unemployment and union leaving in the descriptive analysis. Once we control for firm-level characteristics

\footnotetext{
17 In some of our alternative specifications medium LMA (part-time) was significantly associated with union leaving for men but this effect was not stable.
} 
including contract type, sector and firm-size before unemployment, previous findings which have linked unemployment and union leaving cannot be confirmed for the German context. Finally, the case numbers for some of the other LMA classes (parental leave and mini-jobs) were too low to allow the generation of reliable findings, especially for men. Yet, the fact that female mini-jobbers according to our model are less likely to resign from union membership than unionised women with strong LMA might hint at their determination to remain a union member once unionised: does this reflect the result of organising campaigns in certain sectors like hospitably, and particularly cleaning and retail (Hinz 2012; Riedel 2012)?

\section{Conclusion}

In comparison with union-related reasons for member outflow, unions have only limited influence over external working-life events likely affecting the individual's LMA. Even so, they should not a priori disregard such events, particularly changing employment situations, when developing retention-oriented strategies. To give an example, job insecurity, i.e. uncertainty about retaining a job in the face of threatened lay-off or redundancy, may sometimes contribute to a temptation to resign union membership, but in Belgium, Italy and the Netherlands any such temptation is likely to be fully mediated by perceived union support (De Witte et al. 2008). Unions are thus considered helpful by members feeling insecure about the future of their jobs since such members are particularly in need of advice and information about how to cope with job insecurity (Goslinga 2005). Likewise, if unemployed workers or pensioners decide to leave the union, this might indicate that unions are providing too narrow a range of services for them. Indeed, unemployment has only a weak effect on the outflow in countries such as Belgium, Denmark, Finland and Sweden where unions are still involved, to differing degrees, in the 
administration of the unemployment insurance (Visser 2002). In the German context, the results seem to imply that even if a Ghent system is not in place, also union members becoming longterm unemployed are likely to remain a member when controlling for individual and firm-level characteristics prior to unemployment, but further research is needed here.

Furthermore, to give a second example, if workers are seen to be leaving the union when they change job, this might point to an inadequate union presence at the new workplace or simply no union presence at all (Waddington 2014). Unions' strategic choices could be important here too insofar as the inadequate union presence could well be the result of recruitment strategies predominantly oriented to risk-averse brown-field organising rather than the uncertainty of green-field organising. Within this context, it is worthwhile to refer to the burgeoning literature on the possibilities and limits of transferring the 'organising model' to the German unions as they are confronted with a further de-unionisation trend (Turner 2009). The predominant German understanding of the organising model is, in practice, that it entails emphasizing maximisation of the inflow of new members through the establishment of works councils (Behrens 2009). Moreover, despite its emphasis on union commitment, the possibilities of the organising model for membership retention have been considered less so far, although the specific practice of German unions promoting a 'mitgliederorientierte Tarifpolitik' ${ }^{18}$ (Wohland 2013) in some low-unionised economic branches might be an exception. As the results of our analysis indicate, works councils are not important only as 'recruitment machines' but also as 'retention devices', although the latter seems to hold true only for men and not for women. This seems to signify that any appropriate retention-centred strategy should take gender into account.

\footnotetext{
${ }^{18}$ Unions adopting a 'mitgliederorientierte Tarifpolitik' first set a minimum number of members as a prerequisite before they will negotiate a collective agreement (which applies to all workers).
} 
In addition, though we are far from wishing to claim that union leaving might be the outcome of a single cause, the association between certain LMA classes and union leaving might indicate that such a strategy should also differ according to the LMA class.

Thus, although explanatory in nature, our analysis suggests a number of policy implications for (German) trade unions, which might be confirmed in further research. The SOEP data did not allow for the exploration of union-related determinants for individual leaving behaviour in the German context and due to limited case numbers and deficiencies in the dependent variable a more dynamic LMA tracks analysis was not possible either. Accordingly, future research might embark upon a more dynamic approach by, for example, combining sequence analysis techniques and even history analysis to distinguish between LMA tracks and their possible consequences for unionisation, including leaving behaviour. In our view, such a research endeavour would contribute to revealing the usefulness of the LMA concept. New studies, by taking into account both LMA tracks and union-related determinants, might find more and stronger evidence for the claim that enhancing a life-cycle approach, beyond the workplace, might prove a more promising means for unions of increasing their membership levels than the rather narrow job-centric representation strategy (Budd 2010).

\section{Annex 1. Variables and measurement}

\begin{tabular}{|l|l|}
\hline \multicolumn{1}{|c|}{ Variable } & \multicolumn{1}{c|}{ Measurement } \\
\hline Union leaver (dependent variable) & Union member in 2007 (respectively 2003) but no longer in 2011 \\
& (respectively 2007) \\
\hline Union membership duration & Based on longitudinal information on union membership in the following \\
\hline Retrospective long-term labour & years: 1998, 2001, 2003, 2007 (respectively 1993, 1998, 2001, 2003)* \\
\hline
\end{tabular}




\begin{tabular}{|c|c|}
\hline $\begin{array}{l}\text { market attachment (experience in } \\
\text { part-time, full-time, } \\
\text { unemployment, parental leave) }\end{array}$ & $\begin{array}{l}\text { unemployment over the respondent's life-course and up to the current } \\
\text { observation period. Measured in months using retrospective calendar of event } \\
\text { information combined with retrospective life-history information for } \\
\text { respondents joining the SOEP when already in employment (variable } \\
\text { generated by the SOEP team, see SOEP documentation PGEN, p. 7-9) } \\
\text { Parental leave measured in months prior to the current observation period } \\
\text { (variable generated based on retrospective calendar of event information } \\
\text { available since 1991) }\end{array}$ \\
\hline $\begin{array}{l}\text { Changed job (and sector) in four } \\
\text { year period }\end{array}$ & $\begin{array}{l}\text { Respondents are asked at every interview if they changed job since the last } \\
\text { interview. This information is combined with information on sector of } \\
\text { employment }\end{array}$ \\
\hline $\begin{array}{l}\text { Public/private industry and } \\
\text { services }\end{array}$ & $\begin{array}{l}\text { Calculated from information on detailed sector of employment (NACE) } \\
\text { information and public sector dummy }\end{array}$ \\
\hline
\end{tabular}

Note: The table only contains variables that are constructed from the SOEP data either by the authors or the SOEP team; *This variable cannot take account of information from the refreshment sample which was added to the SOEP population in 2000

\section{Annex 2a. Leaving rates by individual, job and workplace characteristics (choice of} variables), 2007-11

\begin{tabular}{|c|c|}
\hline & $\begin{array}{c}\text { Union } \\
\text { leavers }\end{array}$ \\
\hline Total $(n=1,382)$ & $22.8 \%$ \\
\hline \multicolumn{2}{|l|}{$\begin{array}{l}\text { Gender } \\
\text { (Pearson } \text { chi } 2=9.1154, \operatorname{Pr}=0.003)\end{array}$} \\
\hline $\operatorname{Men}(n=860)$ & $20.5 \%$ \\
\hline Women $(n=522)$ & $26.6 \%$ \\
\hline \multicolumn{2}{|l|}{$\begin{array}{l}\text { Age group } \\
(\text { Pearson } \text { chi } 2=14.5306, \operatorname{Pr}=0.001)\end{array}$} \\
\hline Age $16-35$ years $(n=125)$ & $33.0 \%$ \\
\hline Age $36-49$ years $(n=483)$ & $22.0 \%$ \\
\hline Age $50-64$ years $(n=774)$ & $21.5 \%$ \\
\hline \multicolumn{2}{|l|}{$\begin{array}{l}\text { Union membership duration } * \\
(\text { Pearson chi } 2=27.5927, \operatorname{Pr}=0.000)\end{array}$} \\
\hline$\leq 5$ years $(n=246)$ & $37.6 \%$ \\
\hline $6-9$ years $(n=58)$ & $23.4 \%$ \\
\hline
\end{tabular}




\begin{tabular}{|c|c|}
\hline$\geq 10$ years $(\mathrm{n}=405)$ & $22.2 \%$ \\
\hline \multicolumn{2}{|l|}{$\begin{array}{l}\text { Type of contract } \\
\text { (Pearson chi } 2=35.5620, P r=0.000)\end{array}$} \\
\hline Fixed-term contract $(n=76)$ & $49.0 \%$ \\
\hline Open-ended contract $(\mathrm{n}=1,043)$ & $20.1 \%$ \\
\hline No work contract $(\mathrm{n}=82)$ & $33.5 \%$ \\
\hline \multicolumn{2}{|l|}{$\begin{array}{l}\text { Job changes in period } 2007-2011 \\
(\text { Pearson chi } 2=30.0772, P r=0.000)\end{array}$} \\
\hline Employed without job change $(n=1,015)$ & $19.4 \%$ \\
\hline Employed with job change same sector $(n=124)$ & $23.4 \%$ \\
\hline Employed with job change and sector change $(n=147)$ & $39.3 \%$ \\
\hline \multicolumn{2}{|l|}{$\begin{array}{l}\text { Works council } \\
(\text { Pearson } \text { chi } 2=13.6292, \operatorname{Pr}=0.000)\end{array}$} \\
\hline No works council $(n=157)$ & $34.5 \%$ \\
\hline Works council $(n=1,048)$ & $19.6 \%$ \\
\hline
\end{tabular}

Note: Workplace characteristics are measured in 2007 except for works council in the firm which is available in the 2006 but not the 2007 data.

Note: *This variable cannot take account of information from the refreshment sample which was added to the SOEP population in 2000 .

Source: own calculation based on SOEP v28.

\section{Annex 2b. Leaving rates LMA and gender, 2007-11}

\begin{tabular}{|l|l|l|}
\hline & male & female \\
\hline Strong LMA (n=783) & 17.6 & 14.9 \\
\hline Medium LMA (part-time) (n=156) & 35.0 & 23.4 \\
\hline $\begin{array}{l}\text { Medium LMA (parental leave) } \\
\text { (n=40) }\end{array}$ & 32.6 & 48.9 \\
\hline $\begin{array}{l}\text { Weak LMA (marginal employment) } \\
\text { (n=21) }\end{array}$ & - & 28.8 \\
\hline Weak LMA (unemployment) (n=68) & 27.7 & 33.0 \\
\hline Detachment (retirement) (114) & 43.8 & 58.6 \\
\hline
\end{tabular}

Pearson chi2 male: 21.5421, Pr=0.001; Pearson chi2 female: $19.6487, \operatorname{Pr}=0.001$ 


\section{Data Sources}

Bundesagentur für Arbeit, Statistik nach Themen:

http://statistik.arbeitsagentur.de/Navigation/Statistik/Statistik-nach-Themen/Statistik-nach-

Themen-Nav.html

Eurostat, online database, different series (Labour Force Survey, Income and Living Conditions):

http://epp.eurostat.ec.europa.eu/portal/page/portal/statistics/themes

Socio-economic Panel (SOEP) (2012), Data for years 1984-2011, doi: 10/5684/soep.v28

\section{References}

Addison JT, Schnabel C and Wagner J (2006) The (parlous) state of German unions. Journal of Labor Research 28(1): 3-18.

Addison JT, Bryson A, Teixeira P, Pahnke A and Bellman L (2010) The state of collective bargaining and worker representation in Germany: the erosion continues. Discussion paper No. 5030. IZA, Bonn.

Alós R et al (2009) Diversity in trade union membership. A typology based on the study of a Spanish trade union. Industrial Relations Journal 40(2): 100-121.

Anxo D, Fagan C. Cebrian I and Moreno G (2007) Patterns of labour market integration in Europe - a life course perspective on time policies. Socio-Economic Review 5: 233-260.

Bain G.S. and Elsheikh F. (1976) Union growth and the business cycle: an econometric analysis. Oxford, Basil Blackwell.

Behrens M (2009) Still married after all these years? Union organizing and the role of works councils in German industrial relations. Industrial and Labor Relations Review 62(3): 275293. 
BEEG: Bundeselterngeld- und Elternzeitgesetz vom 5. Dezember 2006 (BGB1. I S. 2748), das zuletzt durch Artikel 1 des Gesetzes vom 15. Februar 2013 (BGBl. I S. 254) geändert worden ist.

Bell D (2012) Labour market attachment: defining the spectrum between the employed and the inactive. Ottawa: Canadian Career Development Foundation.

Blanchflower D G (2007) International patterns of membership. British Journal of Industrial Relations 45(1): 1-28.

Booth AL and Chatterji M (1993) Reputation, membership and wages in an open shop trade union, Oxford Economic Papers 45(1): 23-41.

Bosch G and Weinkopf C (2009) Working for little money: Does Germany really need a minimum wage? Intereconomics (November/December): 353-359.

Budd JW (2010) When do U.S. workers first experience unionization? Implications for revitalizing the labor movement. Industrial Relations 49(2): 209-225.

Bundesagentur für Arbeit (Juli 2014) Statistik der Bundesagentur für Arbeit, Arbeitsmarkt in Deutschland - Zeitreihen bis 2013. Nürnberg.

Bundesagentur für Arbeit (2013) Geringfügig entlohnte Beschäftigung nach ausgewählten Merkmalen. Nürnberg.

Buttigieg DM, Deery SJ and Golsch K (2007) An event history analysis of union joining and leaving. Journal of Applied Psychology 92(3): 829-839.

Cregan C (2013) Does workplace industrial action increase trade union membership? An exchange relationship approach to union joining and leaving behavior. The International Journal of Human Resource Management, 24(17): 3363-3377. 
De Witte $\mathrm{H}$ et al. (2008) Job insecurity, union support and intentions to resign membership: a psychological contract perspective. European Journal of Industrial Relations 14(1): 85-103.

DIW (2014) SOEP documentation, available at at :

http://www.diw.de/en/diw_02.c.239921.en/codebooks.html (accessed 15 August 2014).

Doeringer P and Piore M (1971) Internal labour markets and manpower analysis: Lexington: Heath.

Dribbusch H (2013) Union membership holds up well. EIROline. Available at: http://www.eurofound.europa.eu/eiro/2013/04/articles/de1304019i.htm.

Dribbusch H and Birke P. (2014) The DGB trade unions since the crisis. Developments, challenges, strategies. Berlin, FES.

Ebbinghaus B, Göbel C and Koos S (2011) Social capital, 'Ghent' and workplace contexts matter: Comparing union membership in Europe. European Journal of Industrial Relations 17(2):107-124.

Emmenegger, P, Häusermann, S, Palier, B and Seeleib-Kaiser, M (eds) (2012) The age of Dualization: the Changing Face of Inequality in Deindustrializing Societies, New York: Oxford University Press.

Fagan, C and O'Reilly, J (eds) (2003) Part-time prospects: An international comparison of parttime work in Europe, North America and the Pacific Rim, London: Routledge.

Fitzenberger B, Kohn K and Wang Q (2011) The erosion of union membership in Germany: determinants, densities, decompositions. Journal of Population Economics 24(1): 141-165.

Friedman BA, Abraham SE and Randall KT (2006) Factors related to employees' desire to join and leave unions. Industrial Relations 45(1): 102-110. 
Furåker, B., Berglund, T. (2009) Changes of employer, employment protection and labour market attachment: an analysis of Swedish data from 1972 to 1998. In: Blanpain, R. et al., (ed.) The Modernization of Labour Law and Industrial Relations in a Comparative Perspective. Den Haag: Kluwer, 212-232.

Gallie D (1996) Trade union allegiance and decline in British urban labour markets. In: Gallie D, Penn R and Rose M (eds.) Trade unionism in recession. Oxford: Oxford University Press, pp. $140-174$.

Goerke L and Pannenberg M (2007) Trade union membership and works councils in West Germany. Industrielle Beziehungen 14(2): 154-175.

Gosingla S (2005) Job insecurity, union participation and the need for (new) union services. In: De Witte H (ed.) Job insecurity, union involvement and union activism. Aldershot: Ashgate, pp. 81-96.

Holst, H., Holzschuh, M. Niehoff, S. (2014), YOUnion. Country report Germany. Jena, Friedrich Schiller Universität Jena.

Jódar P, Alós R and Vidal S (2011) Why do workers leave unions? Group differences between workers in CCOO-Catalonia. Transfer 17(4): 471-484.

Gumbrell-McCormick R (2011) European trade unions and 'atypical' workers. Industrial Relations Journal 42(3): 293-310.

Hinz L (2012) Minijobs im Einzelhandel. WSI Mitteilungen, Schwerpunktheft: Minijobs 65(1): 58-60. 
Holst H and Dörre K (2013) Revival of the 'German Model'? Destandardization and the new labour market regime. In: Koch M and Fritz M (eds.) Non-standard employment in Europe. Paradigms, prevalence and policy responses. Basingstoke: Palgrave Macmillan, pp.132149.

Kalleberg A (2003) Flexible Firms and Labor Market Segmentation: Effects of Workplace Restructuring on Jobs and Workers. Work and Occupations 30(2): 154-175.

Klenner C and Lindecke C (2003) Gleichstellung von Frauen und Männern in der betrieblichen Interessenvertretung. WSI-Mitteilungen 56(3): 177-184.

Klenner C. et al. (2013) Förderung der Vereinbarkeit von Familie und Beruf in Tarifverträgen und Betriebsvereinbarungen in Deutschland. Eine empirische Analyse. WSIDiskussionspapier No. 184. Düsseldorf: WSI.

Laux R (1997) Measuring labour market attachment using the labour force survey. Labour Market Trends. London: HMSO.

Leschke J (2013) La crise économique a-t-elle accentué la segmentation du marché du travail et de la protection sociale ? Une analyse des pays de l'UE (2008-2010). Revue Française des Affaires Sociales, Special Issue: "Emplois et statuts atypiques: quelles protections sociales? (4).

Marino S (2012) Trade union inclusion of migrant and ethnic minority workers: comparing Italy and the Netherlands. European Journal of Industrial Relations 18(1): 5-20.

Martínez Lucio M (2013) Broadening and reimagining regulation: trade unions, 'active servicing' and immigration in Spain since the early 1990s. Journal of Industrial Relations 55(2): 190-211. 
Minijob-Zentrale (2015) Aktuelle Entwicklungen im Bereich der geringfügigen Beschäftigung: 1.

Quartal 2015. Deutsche Rentenversicherung Knappschaft-Bahn-See / Minijob-Zentrale.

Mückenberger U (1989) Der Wandel des Normalarbeitsverhältnisses unter Bedingungen einer „Krise der Normalität“. Gewerkschaftliche Monatshefte 4(89): 211-223.

Muffels R and Fouarge D (2002) Employment regimes and labour market attachment: evidence form the ECHP. In: Muffels R, Tsakloglou P and Mayes D (eds.) Social exclusion in European welfare states. Cheltenham: Edward Elgar, pp. 51-77.

Oesch D (2012) Recruitment, retention and exit from union membership. An analysis of member flows in Swiss union locals. British Journal of Industrial Relations 50(2): 287-307.

O’Reilly J and Bothfeld S (2002) What happens after working part-time ? Integration, maintenance or exclusionary Germany. Cambridge Journal of Economic 26: 409-439.

Reich M, Gordon DM and Edwards RC (1973) Dual labor markets: a theory of labor market segmentation. American Economic Review 63(2): 359-365

Rhein T (2013) Deutsche Geringverdiener im europäischen Vergleich. IAB-Kurzbericht 15. Institut für Arbeitsmarkt- und Berufsforschung: Nürnberg.

Riedel P (2012) Minijobs in der Gebäudereinigung. WSI Mitteilungen, Schwerpunktheft: Minijobs 65(1): 64-67.

Rubery J (2011) Towards a gendering of the labour market regulation debate. Cambridge Journal of Economics 35: 1103-1126.

Schnabel C (2013) Union membership and density: Some (not so) stylized facts and challenges. European Journal of Industrial Relations 19(3): 255-272.

Schnabel C and Wagner J (2012) With or without U? Testing the hypothesis of an inverted Ushaped union membership-age relationship. Contemporary Economics 6(4): 28-34. 
Schulze Buschoff K and Protsch P (2008) '(A-)typical and (in-)secure? Social protection and "non-standard" forms of employment in Europe'. International Social Security Review 61(4): 51-73.

Simonson, J, Romeu Gordo, L and Titova, N (2011) Changing employment patterns of women in Germany: How do baby boomers differ from older cohorts? A comparison using sequence analysis, Volume 16, Issue 2, June 2011, Pages 65-82

Statistisches Bundesamt (2015) Öffentliche Sozialleistungen - Statistik zum Elterngeld:

Beendete Leistungsbezüge für im 4. Vierteljahr 2013 geborene Kinder, Oktober 2013 bis März 2015, Wiesbaden.

Solon G, Haider S and Wooldridge J (2013) What are we weighting for? NBER Working Paper Series. National Bureau of Economic Research: Cambridge.

Thomas A (2013) Towards the managerialization of trade unions? Recent trends in France and Germany. European Journal of Industrial Relations 19(1): 21-36.

Turner L (2009) Institutions and activism. Crisis and opportunity for a German labor movement in decline. Industrial and Labor Relations Review 62(3): 294-312.

TzBfG: Teilzeit- und Befristungsgesetz, 21. December 2000 (BGBl. I S. 1966), most recent change: article 23 (20. December 2011 (BGBl. I S. 2854)).

Vandaele K and Leschke J (2010) Following the 'organising model' of British unions?

Organising non-standard workers in Germany and the Netherlands. Working Paper 2010.02. European Trade Union Institute: Brussels.

Van Rij C and Saris W (1993) Time dependency of trade union membership. An event-history analysis. Quality and Quantity Journal 27(1): 73-93. 
Vaona A (2010) A survival analysis approach to the duration of union membership in Italy. Applied Economic Letters 17: 1089-1093.

Vidal S, Alós R, Jódar P and Beneyto P (2013) Membership duration in a Spanish union: a survival analysis. Economic and Industrial Democracy, Epub ahead of print 16 July 2013, doi: $10.1177 / 0143831 X 13489358$

Virtanen P et al. (2011) Tracks of labour market attachment in early middle age: a trajectory analysis over 12 years. Advances in Life Course Research 16(2): 55-64.

Visser J (2002) Why fewer workers join unions in Europe: A social custom explanation of membership trends. British Journal of Industrial Relations 40(3): 403-430.

Waddington J (2014) Trade union membership retention in Europe: The challenge of difficult times. European Journal of Industrial Relations, Epub ahead of print 20 June 2014, doi: $10.1177 / 0959680114538708$.

Waddington J (2006) Why Do Members Leave? The Importance of Retention to Trade Union Growth. Labor Studies Journal 36(3): 15-38.

Waddington J and Kerr A (1999a) Membership retention in the public sector. Industrial Relations Journal 30(2): 151-165.

Waddington J and Kerr A (1999b) Trying to stem the flow: union membership turnover in the public sector. Industrial Relations Journal 30(3): 184-196.

Waenerlund, A.-K et al. (2014) History of labour market attachment as a determinant of heatlh status: a 12-year follow-up of the Northern Swedish cohort, BMJ Open, 4(2), doi:10.1136/bmjopen-2013-004053

Wanger S (2011) Ungenutzte Potenziale in der Teilzeit: Viele Frauen würden gerne länger arbeiten. IAB-Kurzbericht 9. Institut für Arbeitsmarkt- und Berufsforschung: Nürnberg. 
Wohland U (2013) Kampagnen, Organizing und mitgliederorientierte Tarifpolitik. Konzepte und Praxis. In: Kocsis A, Sterkel G and Wiedemuth, J. (eds.) Organisieren am Konflikt. Tarifauseinandersetzungen und Mitgliederentwicklung im Dienstleistungssektor. Hamburg: VSA-Verlag, pp.65-76. 